J-SANAK: Jurnal Kajian Anak

(p-ISSN: 2686-5343 |e-ISSN: 2715-7989)

Vol.(2)(01), (Juli-Desember)(2020), (Halaman)(49-59)

DOI: https://doi.org/10.24127/j-sanak.v2i01.384

\title{
PENGEMBANGAN MEDIA TALOKA (TALI LOMPAT ANGKA) UNTUK MENINGKATKAN KEMAMPUAN MENGENAL ANGKA PADA ANAK USIA DINI
}

\author{
Indaria Hariyani ${ }^{1}$ \\ Sekolah Tinggi Keguruan dan Ilmu Pendidikan Bina Insan Mandiri Surabaya \\ indariahariyani@gmail.com
}

\begin{abstract}
ABSTRAK
Pengenalan angka pada anak tidak hanya sekedar mengenal lambang dari suatu bilangan, akan tetapi anak mampu mengetahui makna atau nilai dari suatu bilangan. Tujuan penelitian ini adalah untuk mengembangkan Media TALOKA (Tali Lompat Angka) yang dirasa menarik untuk mengatasi permasalahan yang ada khususnya pada kemampuan mengenal angka pada anak usia dini. Metode pengembangan yang dilakukan dalam penelitian ini adalah modifikasi dari model pengembangan 4D Thiagarajan. Data yang dihasilkan akan dianalisis dengan menggunakan analisis deskriptif kualitatif, analisis deskriptif kuantitatif dan uji t. Hasil penelitian menunjukkan bahwa Media TALOKA (Tali Lompat Angka) dapat meningkatkan kemampuan mengenal angka pada anak usia dini. Dari hasil analisis data memperoleh memperoleh nilai signifikasi 0,000 < 0,005 maka H0 ditolak. Dengan demikian dapat dikatakan adanya perbedaan pada rata-rata perlakuan sebelum dan sesudah dan rata-rata skor perlakuan sebelum dan sesudah perlakuan pada proses pembelajaran dengan menggunakan Media TALOKA (Tali Lompat Angka) yang telah dikembangkan. Perbedaan nilai rata-rata kelompok eksperimen dan kelompok kontrol membuktikan bahwa dengan menggunakan Media TALOKA (Tali Lompat Angka) yang telah dikembangkan dapat meningkatkan kemampuan mengenal angka pada anak usia dini.
\end{abstract}

Kata Kunci: Media TALOKA; kemampuan mengenal angka; anak usia dini.

Received 15-11-2020; Received in revised form 25-12-2020; Accepted 28-12-2020

\begin{abstract}
The recognition of numbers in children is not only about knowing the symbol of a number, but children can know the meaning or value of a number. The purpose of this research is to develop TALOKA media which is considered interesting to solve the existing problems, especially in the ability to recognize numbers in early childhood. The development method used in this study is a modification of the 4D Thiagarajan development model. The resulting data will be analyzed using qualitative descriptive analysis, quantitative descriptive analysis, and t-test. The results showed that TALOKA media can improve the ability to recognize numbers in early childhood. From the results of data analysis obtained a significance value of $0.000<0.005$, then $\mathrm{HO}$ is rejected. Thus it can be said that there is a difference in the average before and after treatment and the average score of the treatment before and after treatment in the learning process using TALOKA Media that has been developed. The difference in the mean value of the experimental group and the control group
\end{abstract}


proves that using the TALOKA Media that has been developed can improve the ability to recognize numbers in early childhood.

Keywords: TALOKA Media; the ability to recognize numbers; early childhood

\section{A. PENDAHULUAN}

Pendidikan anak usia dini merupakan jenjang pendidikan yang penting khususnya bagi tumbuh kembang anak. Anak usia dini disebut golden age karena pada usia ini pertumbuhan dan perkembangan fisik motorik, sosial emosional, kognitif, dan bahasa berlangsung dengan sangat pesat (Suyanto, 2005). Salah satu aspek dalam pengembangan kognitif adalah mengenal angka. Mengenal angka merupakan bagian tidak terpisahkan dari kehidupan yang sangat diperlukan dalam kehidupan sehari-hari. Kemampuan mengenal angka anak harus dilakukan semenjak anak usia dini. Hanya saja beberapa lembaga pendidikan dalam pembelajarannya kurang menstimulasi anak untuk mengenal angka, seperti menyediakan berbagai macam media/alat, memberikan kesempatan untuk mencoba berbagai cara memainkannya, serta metode dalam meningkatkan kemampuan kemampuan mengenal angka. (Anggrayni \& Sari, 2019).

Salah satu aspek perkembangan yang harus dikembangkan dalam pembelajaran anak usia dini adalah aspek kognitif. Dalam Permendikbud No. 137 Tahun 2014 (Permendikbud, 2014) tentang Standar Nasional PAUD menyebutkan bahwa aspek kognitif meliputi: Belajar dan pemecahan masalah, mencakup kemampuan memecahkan masalah sederhana dalam kehidupan sehari-hari dengan cara fleksibel dan diterima sosial serta menerapkan pengetahuan atau pengalaman dalam konteks yang baru; Berfikir logis, mencakup berbagai perbedaan, klasifikasi, pola berinisiatif, berencana, dan mengenal sebab-akibat; Berpikir simbolik, mencakup kemampuan mengenal, menyebutkan, dan menggunakan konsep bilangan, mengenal huruf, serta mampu merepresentasikan berbagai benda dan imajinasinya dalam bentuk gambar. Dalam Permendikbud No.137 tahun 2014 tentang STPPA (Standar Tingkat Pencapaian Perkembangan Anak) disebutkan bahwa indikator yang harus dicapai untuk anak usia 4-5 tahun yaitu membilang banyak benda 1-10, mengenal konsep bilangan, dan mengenal lambang bilangan.(Rahman et al., 2017).

Pengenalan lambang bilangan sangat penting bagi anak usia dini. Banyak hal disekitar anak yang berhubungan dengan lambang bilangan. Lambang bilangan merupakan aspek dasar dalam matematika. Pengalaman matematika harus disesuaikan dengan perkembangan kognitif anak agar meminimalkan kesulitan persepsi. Mengenalkan lambang bilangan untuk anak usia dini harus disesuaikan dengan perkembangan kognitif anak. Dengan mengenal lambang bilangan akan memudahkan anak dalam menyampaikan dan menafsirkan berbagai informasi. 
J-SANAK: Jurnal Kajian Anak

(p-ISSN: 2686-5343 |e-ISSN: 2715-7989)

Vol.(2)(01), (Juli-Desember)(2020), (Halaman)(49-59)

DOI: https://doi.org/10.24127/j-sanak.v2i01.384

Pada awalnya anak mampu menyebutkan bilangan tanpa mengetahui makna bilangan tersebut. Sejalan dengan perkembangan dan pengalaman yang diperoleh anak akan mampu mengenal lambang bilangan (Sumardi et al., 2017).

Anak usia taman kanak-kanak berada di perkembangan kognitif telah memiliki kemampuan dasar pengetahuan alam sekitar dan tentang matematika. Perkembangan pengetahuan alam sekitar pada anak dilihat dari kemampuan menyebutkan nama objek yang ada disekitarnya, menjelaskan tentang peristiwa yang terjadi, serta hal-hal lainya. Perkembangan matematika dapat dilihat dari kemampuan anak dalam konsep bilangan, menghitung batas tertentu dan bahkan ada yang telah dapat melakukan operasi hitung secara sederhana (Jamaris, 2006). Konsep matematika yang perlu dikenalkan pada anak yaitu berhubungan dengan lambang bilangan atau angka.

Kemampuan adalah kesanggupan mengenai sesuatu yang diperoleh seseorang melalui latihan yang teratur dan terarah. Kemampuan menunjukkan bahwa suatu tindakan dapat dilakukan sekarang. Pendapat tersebut dapat diartikan bahwa kemampuan perwujudan dari bakat yang telah dilatih melalui pembelajaran yang kemudian dapat menjadi suatu tindakan yang terencana serta dilakukan pada saat diperlukan. Seseorang dapat dikatakan mempunyai kemampuan apabila orang tersebut memiliki sejumlah keterampilan atau kecakapan yang dipadukan secara utuh dan melewati suatu proses yang insentif (Hasanah \& Nurhasanah, 2020).

Pengenalan angka sangat penting dikuasai oleh anak, sebab akan menjadi dasar bagi penguasaan konsep-konsep matematika selanjutnya di jenjang pendidikan berikutnya. Pengenalan konsep angka kepada anak, memerlukan cara dan stimulasi yang tepat dan menyenangkan. Salah satunya adalah melalui berbagai media pembelajaran. Prinsipnya media pembelajaran di TK hendaknya dirancang secara tepat sesuai dengan karakteristik dunia anak. Ketepatan dan kesesuaian penggunaan media pembelajaran sangat penting karena bisa berdampak terhadap cara dan proses pembelajaran anak, serta dapat mengembangkan berbagai potensi dan kemampuan anak secara optimal. Salah satu media yang digunakan dalam proses pembelajaran pada anak terutama dalam mengenal angka diantaranya adalah Media TALOKA (Tali Lompat Angka) yang diharapkan dapat memberi pengalaman bermakna dan meningkatkan kemampuan mengenal angka anak khususnya pada kecerdasan matematika.

Berdasarkan hasil observasi awal bulan September tahun 2020 di TK A Muslimat NU 80 pada anak kelompok A terlihat kemampuan anak mengenal angka 1- 10 rendah. Hasil ini buktikan dari ketika anak diminta untuk menyebutkan angka hanya sejumlah 3 anak yang mampu, untuk mengurutkan angka hanya sejumlah 1 anak yang mampu, dan memasangkan angka dengan jumlah benda hanya sejumlah 2 anak yang mampu. Mengenal angka dalam pembelajaran di kelas guru masih monoton yaitu menggunakan lembar kerja anak dan papan tulis, terlihat anak bosan 
J-SANAK: Jurnal Kajian Anak

(p-ISSN: 2686-5343 |e-ISSN: 2715-7989)

Vol.(2)(01), (Juli-Desember)(2020), (Halaman)(49-59)

DOI: https://doi.org/10.24127/j-sanak.v2i01.384

dengan pembelajaran pengenalan angka. Kebosanan itu terlihat dari perilaku anak berbicara sendiri dengan temannya ketika guru menerangkan, anak bermain sendiri, anak duduk dengan kepala ditaruh di meja dan terkadang anak tidak selesai mengerjakan tugas dari guru dan malah mencontek tugas temannya. Upaya yang dapat dilakukan untuk mengembangkan kemampuan mengenal lambang bilangan 1-10 pada anak yaitu dengan kegiatan pembelajaran yang menarik minat anak, menyenangkan, serta media pembelajaran yang tepat sesuai dengan karakteristik dan tahap perkembangan anak, agar potensi yang mereka miliki dapat berkembang secara optimal (Gandana et al., 2017). Berdasarkan masalah di atas, peneliti telah mencoba membuat suatu Media TALOKA (Tali Lompat Angka) untuk meningkatkan kemampuan mengenal angka pada anak kelompok A dengan cara yang menyenangkan serta dapat menarik minat dan perhatian anak. Berdasarkan latar belakang diatas, maka pertanyaan penelitian yang harus dipecahkan yakni: Bagaimanakah hasil pengembangan Media TALOKA (Tali Lompat Angka) untuk meningkatkan kemampuan mengenal angka pada anak kelompok A? Apakah Media TALOKA (Tali Lompat Angka) yang dikembangkan layak untuk meningkatkan kemampuan mengenal angka pada anak kelompok A?

\section{B. METODOLOGI}

\section{Tahapan Penelitian}

Gambar 1. Diagram Alur Pengembangan Perangkat Model 4-D (Four D Model)

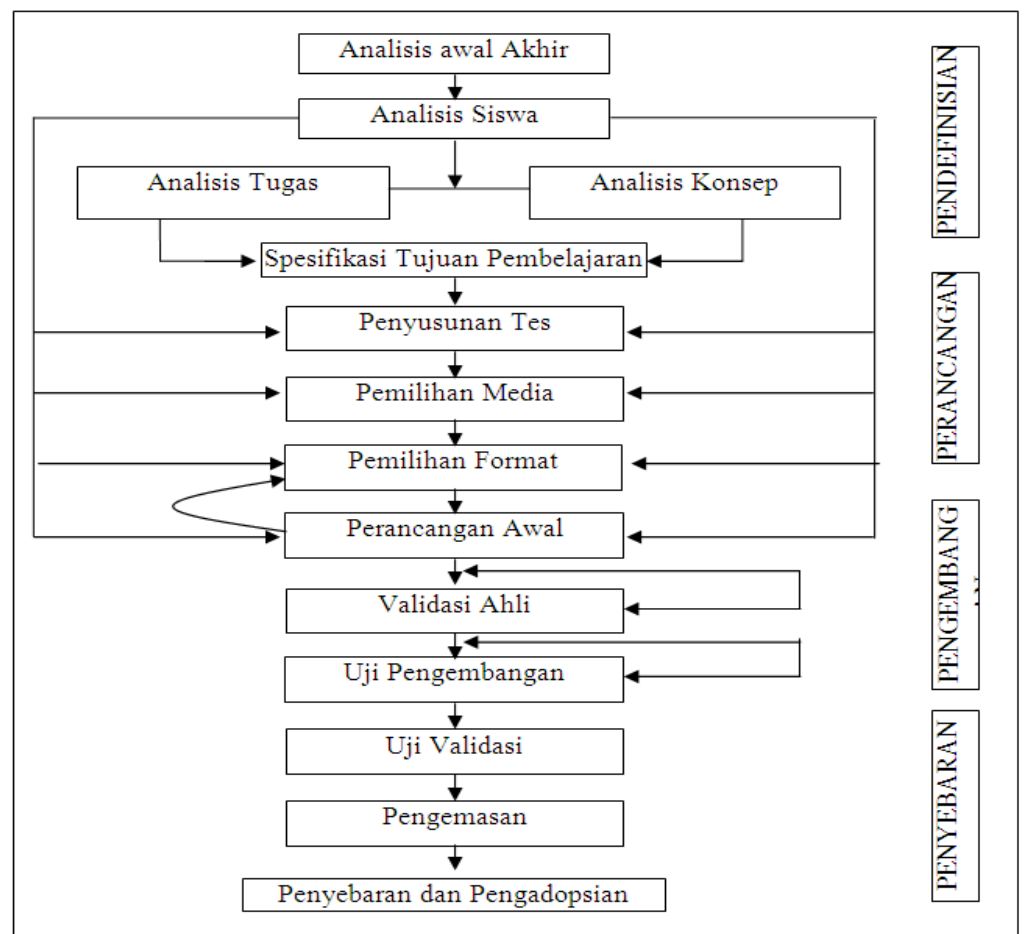

Copyright $($ ) 2020, Universitas Muhammadiyah Metro| 52 
J-SANAK: Jurnal Kajian Anak

(p-ISSN: 2686-5343 |e-ISSN: 2715-7989)

Vol.(2)(01), (Juli-Desember)(2020), (Halaman)(49-59)

DOI: https://doi.org/10.24127/j-sanak.v2i01.384

Dalam penelitian pengembangan ini, peneliti menggunakan model ini hanya pada 3 tahapan saja yaitu: define, design, dan develop. Untuk tahapan keempat yaitu disseminate tidak dilakukan oleh peneliti pada penelitian ini. Peneliti tidak melaksanakan tahapan ini dikarenakan beberapa pertimbangan yakni memerlukan waktu yang lama dan biaya yang banyak.

\section{Kerangka Kerja Penelitian}

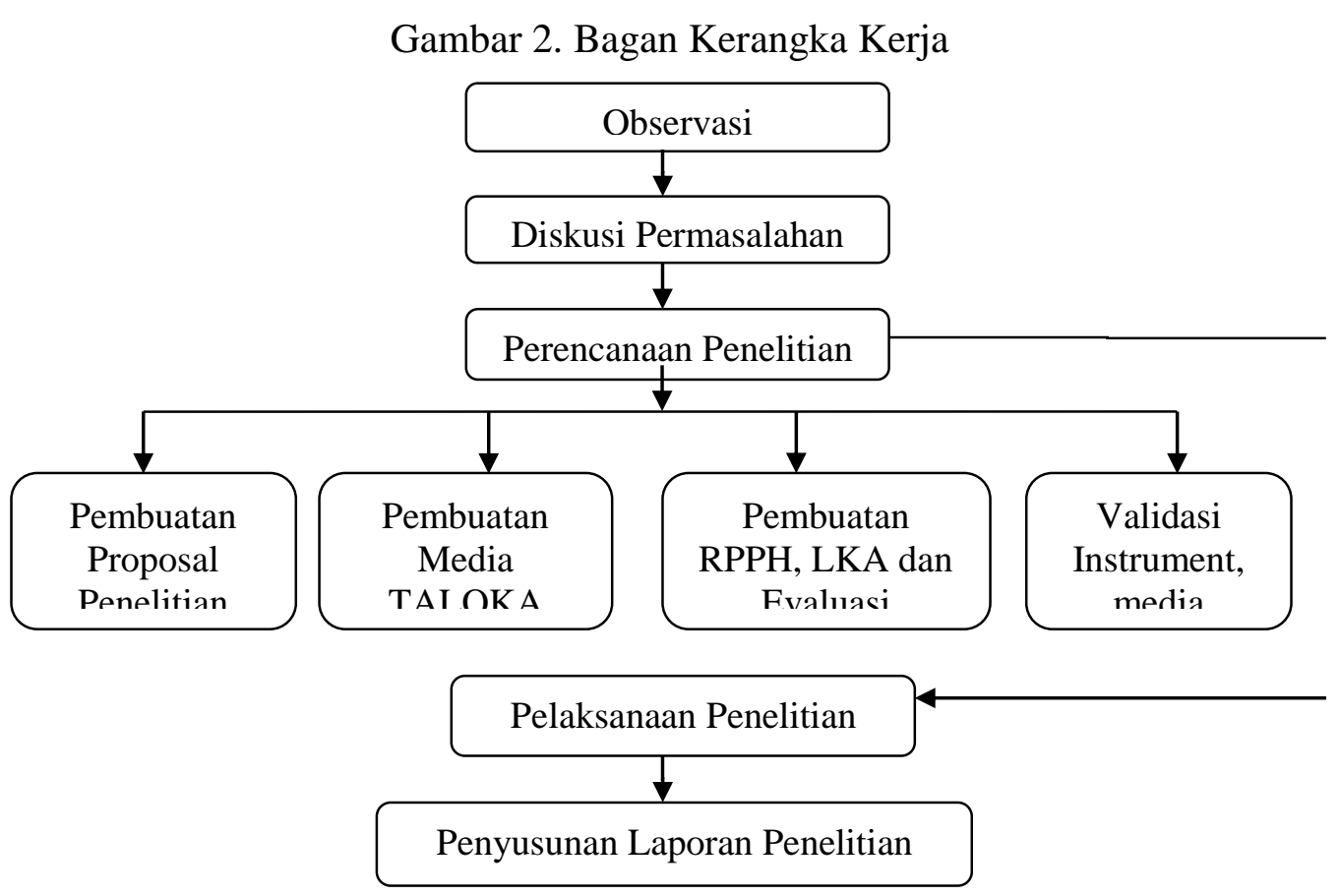

Tabel 1. Penjelasan Tentang Kerangka Kerja Penelitian

\begin{tabular}{|l|l|l|}
\hline Pelaksanaan & Penelitian & Rancangan Indikator \\
\hline Observasi & $\begin{array}{l}\text { Mencari masalah yang } \\
\text { terjadi selama kegiatan } \\
\text { pembelajaran berlangsung } \\
\text { di TK A Muslimat NU 80 } \\
\text { Sidoarjo }\end{array}$ & $\begin{array}{l}\text { Menemukan permasalahan } \\
\text { yang terjadi selama kegiatan } \\
\text { pembelajaran berlangsung, } \\
\text { menganalisis faktor-faktor } \\
\text { yang menyebabkan } \\
\text { permasalahan terjadi. }\end{array}$ \\
\hline $\begin{array}{l}\text { Diskusi } \\
\text { Permasalahan }\end{array}$ & $\begin{array}{l}\text { Diskusi dengan teman } \\
\text { sejawat yakni dosen PG- } \\
\text { PAUD STKIP BIM } \\
\text { SURABAYA. }\end{array}$ & $\begin{array}{l}\text { Menemukan solusi dari } \\
\text { permasalahan tersebut. }\end{array}$ \\
\hline $\begin{array}{l}\text { Perencanaan } \\
\text { Penelitian }\end{array}$ & $\begin{array}{l}\text { Merancang membuat } \\
\text { proposal penelitian, } \\
\text { pembuatan media taloka, }\end{array}$ & $\begin{array}{l}\text { Membuat proposal penelitian, } \\
\text { pembuatan media, pembuatan }\end{array}$ \\
\hline
\end{tabular}


J-SANAK: Jurnal Kajian Anak

(p-ISSN: 2686-5343 |e-ISSN: 2715-7989)

Vol.(2)(01), (Juli-Desember)(2020), (Halaman)(49-59)

DOI: https://doi.org/10.24127/j-sanak.v2i01.384

\begin{tabular}{|l|l|l|}
\hline & $\begin{array}{l}\text { pembuatan (RPPH, LKA, } \\
\text { Evaluasi), Validasi } \\
\text { instrument dan media }\end{array}$ & $\begin{array}{l}\text { (RPPH, LKA, Evaluasi), } \\
\text { validasi } \\
\text { Instrument dan media. }\end{array}$ \\
\hline $\begin{array}{l}\text { Pelaksanaan } \\
\text { Penelitian }\end{array}$ & $\begin{array}{l}\text { Merancang eksperimen } \\
\text { dengan menggunakan kelas } \\
\text { eksperimen dan kelas } \\
\text { kontrol. }\end{array}$ & $\begin{array}{l}\text { Melaksanakan eksperimen } \\
\text { dengan menggunakan kelas } \\
\text { eksperimen dan kelas kontrol. } \\
\text { Kemudian membandingkan } \\
\text { hasil penelitian. }\end{array}$ \\
\hline $\begin{array}{l}\text { Penyunsunan } \\
\text { Laporan } \\
\text { penelitian }\end{array}$ & $\begin{array}{l}\text { Menyunsun rancangan } \\
\text { penelitian. }\end{array}$ & Membuat laporan penelitian \\
\hline
\end{tabular}

\section{Prosedur Penelitian}

\section{Tahap Pendefinisian}

Pada tahap ini dilakukan kegiatan yang meliputi analisis awal-akhir, anilisis siswa, analisis tugas, analisis konsep dan perumusan tujuan pembelajaran.

a) Analisis Awal-Akhir. Tujuan analisis ini adalah untuk mengetahui masalah dasar yang dihadapi guru kelas TK A Muslimat NU 80 Sidoarjo sehingga dibutuhkan pengembangan bahan pembelajaran.

b) Analisis Siswa. Dalam mengidentifikasi perilaku awal dan karakteristik anak dilakukan melalui data wawancara dari guru. Data diambil dari anak Kelompok A yang berada pada rentang usia 4-5 tahun.

c) Analisis Tugas. Analisis tugas disesuaikan dengan tujuan pembelajaran dan indikator yang akan dicapai.

d) Analisis Konsep. Analisis konsep merupakan identifikasi konsepkonsep yang relevan untuk pengembangan bahan ajar dengan tema kebutuhanku dan sub tema makanan. Di dalam Media TALOKA (Tali Lompat Angka) yaitu di dalamnya menjelaskan tambah kurang dengan media yang menyenangkan.

e) Perumusan Tujuan Pembelajaran. Tujuan dari analisis ini adalah untuk mengetahui aspek kemampuan mengenal angka khususnya pada kecerdasan matematika.

\section{Tahap Perancangan}

Tahap ini bertujuan untuk merancang perangkat pembelajaran, meliputi:

a) Penyusunan Tes. Dasar penyusunan tes adalah analisis materi yang dijabarkan dalam indikator pencapaian hasil belajar. Untuk merancang tes ini, terlebih dahulu dibuat kisi-kisi tes dan pedoman skor.

b) Pemilihan Media Pembelajaran. Pemilihan media pembelajaran berkenaan dengan penentuan media yang tepat dan sesuai untuk 
menyajikan materi pembelajaran. Media yang digunakan dalam penelitian ini adalah Media TALOKA (Tali Lompat Angka).

c) Pemilihan Format. Pemilihan format erat kaitannya dengan pemilihan media pembelajaran.

\section{Tahap Pengembangan}

Tahap ini meliputi validasi perangkat oleh validator diikuti dengan revisi, uji coba kelompok kecil yaitu kegiatan mengoperasionalkan RPPH, dan uji coba lapangan.

a) Validasi oleh Validator. Pada tahap ini dilakukan desain uji kelayakan draf 1 berupa media TALOKA (tali lompat angka) yang di dalamnya menjelaskan konsep mengenal angka. Uji coba ini meliputi uji coba ahli media pembelajaran, uji coba ahli materi dan uji coba ahli pembelajaran. Dari hasil penelitian ahli akan dianalisis dan hasilnya akan menentukan revisi atau tidaknya desain produk yang dihasilkan. Bila perlu direvisi, maka hasil validasi dijadikan bahan revisi untuk menghasilkan draf II, sampai akhirnya bahwa produk tersebut layak diuji coba kan

b) Uji Coba Terbatas. Pada tahap ini pengujian dilakukan pada beberapa anak untuk mendapatkan respon anak dari materi yang diajarkan, hasilnya digunakan sebagai revisi produk yang akan menghasilkan draf III. Tahap ini dilakukan oleh peneliti kepada 14 anak TK Kelompok A dan guru kelas nya. Tahap ini bertujuan untuk mengetahui ke menarikan dan kesesuaian media pembelajaran yang dikembangkan.

c) Uji Coba Lapangan. Pada tahap ini pengujian dilakukan pada uji lapangan dengan menerapkan media pembelajaran TALOKA pada Kelompok A. Hasil uji coba akan dijadikan bahan revisi sehingga produk siap dipakai. Tahap uji coba lapangan dilakukan pada evaluasi summative. Uji coba lapangan ini dilakukan pada anak TK Kelompok A dan guru kelas nya. Pada tahap ini juga akan diadakan pretest dan posttest di awal dan di akhir tahap uji lapangan untuk mengetahui pencapaian kemampuan.

\section{Teknik Pengolahan dan Analisis Data}

Desain uji coba yang digunakan adalah tipe One Group Pre-Test dan PostTest Design. 
Gambar 3.2 Desain Eksperimen One Group Pre-Test dan Post-Test Design (Sugiyono, n.d.)

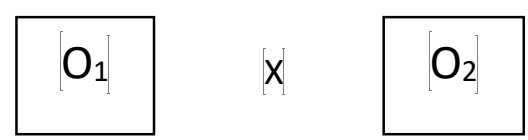

$\mathrm{O}_{1}$ adalah nilai hasil pemerolehan peningkatan kemampuan mengenal angka anak Kelompok A sebelum menggunakan media pembelajaran berupa media TALOKA (tali lompat angka), sedangkan $\mathrm{O}_{2}$ adalah nilai hasil peningkatan kemampuan mengenal angka anak kelompok A sesudah menggunakan media pembelajaran berupa media TALOKA (tali lompat angka).

Untuk membuktikan signifikan perbedaan hasil pretest dan posttest dihitung di sekolah yang dijadikan penelitian. Jadi media pembelajaran untuk mengenalkan media TALOKA (tali lompat angka) sampai delapan belas anak TK A jika taraf signifikannya adalah 0,05. Adapun rumus yang digunakan adalah sebagai berikut :

Keterangan:

$$
t=\frac{M d}{\sqrt{\frac{\sum x^{2} d}{N(N-1)}}}(\text { Suharsimi, 2006) }
$$

$M d=$ Mean dari deviasi (d)antara pretest dan posttest

$x^{2} d=$ Perbedaan deviasi dengan mean diviasi

$N=$ Banyaknya objek

$d f=$ Atau $d b$ adalah

\section{HASIL DAN PEMBAHASAN}

Hasil analisis data dari pengembangan produk media pembelajaran berupa Media TALOKA (Tali Lompat Angka), menunjukkan kelayakan pada hasil uji coba ahli media, ahli materi, ahli pembelajaran, uji coba perorangan dan uji coba kelompok kecil.

Hasil angket yang telah divalidasi oleh ahli media menyatakan bahwa Media TALOKA (Tali Lompat Angka) yang telah dikembangkan menunjukkan bahwa dari seluruh variabel dan sub variabel dinyatakan layak, sehingga dapat dikatakan bahwa media tersebut layak digunakan dari sisi kualitas isi, dan kualitas instruksional. Validator menunjukkan bahwa Media TALOKA (Tali Lompat Angka) ini dapat digunakan dan ditindaklanjuti pada uji kelompok kecil.

Penilaian dari ahli materi dengan variabel komponen materi, pengorganisasian komponen materi, pemilihan media belajar, dan kegiatan Media TALOKA (Tali Lompat Angka) dari seluruh variabel dan sub variabel sesuai sehingga dapat dikatakan layak digunakan. Catatan yang diberikan bahwa pada RPPH (Rencana Pelaksanaan Pembelajaran Harian) pada kolom metode pembelajaran ada yang 
J-SANAK: Jurnal Kajian Anak

(p-ISSN: 2686-5343 |e-ISSN: 2715-7989)

Vol.(2)(01), (Juli-Desember)(2020), (Halaman)(49-59)

DOI: https://doi.org/10.24127/j-sanak.v2i01.384

belum benar tetapi pada akhirnya sudah dibetulkan oleh peneliti. Pada penilaian pembelajaran kolom rubrik penilaian belum dijelaskan secara jelas sehingga peneliti perlu merevisi sedikit.

Selanjutnya adalah validasi yang disampaikan oleh ahli desain pembelajaran anak usia dini, dari variabel dan indikator adalah sesuai sehingga dapat dikatakan media tersebut layak digunakan dari sisi materi dan bahasa yang ditampilkan. Menurut catatan yang diberikan bahwa dari variabel bahasa seharusnya perlu perbaikan dari redaksi bahasa tentang orang yang tidak dikenal.

Untuk uji coba terbatas atau uji coba kelompok kecil dilakukan kepada 18 anak dari kelompok A dari enam pertanyaan bahwa sebagian besar (94,4\%) anggota kelompok kecil memberikan jawaban "ya" dan hanya sebagian kecil $(5,6 \%)$ memberikan jawaban "tidak" sehingga dapat dikatakan Media TALOKA (Tali Lompat Angka) tersebut layak untuk digunakan.

Dari uji kelompok besar/ uji lapangan pada kelompok eksperimen dan kelompok kontrol diperoleh perhitungan dengan menggunakan uji $t$ untuk mengetahui peningkatan kemampuan anak usia dini dalam mengenal Media TALOKA (Tali Lompat Angka). Ada 4 konsep yang diujicobakan pada kelompok eksperimen yang menggunakan video dan kelompok kontrol tanpa menggunakan media.

Pengenalan Media TALOKA (Tali Lompat Angka) dengan konsep mengenal angka memperoleh nilai signifikansi $0,000<0,005$ maka $\mathrm{H}_{0}$ ditolak. Dengan demikian dapat dikatakan adanya perbedaan pada rata-rata perlakuan sebelum dan sesudah dan rata-rata skor perlakuan sebelum dan sesudah perlakuan pada proses pembelajaran tali lompat dengan menggunakan Media TALOKA (Tali Lompat Angka) yang telah dikembangkan. Dengan kata lain bahwa dengan menggunakan Media TALOKA (Tali Lompat Angka) dapat menstimulasi kemampuan mengenal angka pada anak usia dini.

Dari hasil perhitungan di atas pada pengenalan konsep tersebut dapat disimpulkan bahwa dengan menggunakan Media TALOKA (Tali Lompat Angka) yang telah dikembangkan dapat menstimulasi kemampuan mengenal angka pada anak usia dini.

Dari hasil uji coba lapangan menunjukkan adanya ke efektifitas nya dalam kegiatan pembelajaran dengan meningkatnya kemampuan anak dalam Media TALOKA (Tali Lompat Angka) yang dibuktikan melalui peningkatan hasil belajar pada kelompok eksperimen.

Media pembelajaran tali lompat berupa media TALOKA (Tali Lompat Angka) yang telah dikembangkan dalam penelitian ini merupakan produk pengembangan yang bertujuan untuk menstimulasi kemampuan mengenal angka anak usia dini pada kelompok A TK Muslimat NU 80 Sidoarjo. Hasil uji lapangan ditemukan bahwa penggunaan tali lompat berupa media TALOKA (Tali Lompat Angka) yang 
J-SANAK: Jurnal Kajian Anak

(p-ISSN: 2686-5343 le-ISSN: 2715-7989)

Vol.(2)(01), (Juli-Desember)(2020), (Halaman)(49-59)

DOI: https://doi.org/10.24127/j-sanak.v2i01.384

dikembangkan terbukti efektif menstimulasi kemampuan mengenal angka pada anak usia dini kelompok A TK Muslimat NU 80 Sidoarjo.

\section{KESIMPULAN}

Berdasarkan data dan pembahasan yang telah diperoleh maka proses pengembangan dan uji coba produk media berupa media TALOKA (Tali Lompat Angka) untuk menstimulasi kemampuan mengenal angka pada anak usia dini dapat disimpulkan bahwa: hasil penelitian menunjukkan implementasi media TALOKA (Tali Lompat Angka) ini sangat menarik bagi anak dan dapat mendukung proses pembelajaran yang sedang berlangsung, sehingga perkembangan kemampuan mengenal angka sesuai dengan peraturan Menteri Pendidikan Nasional nomor 58 dapat meningkat. Kemudian penggunaan media TALOKA (Tali Lompat Angka) dalam bentuk media terbukti efektif dapat menstimulasi kemampuan mengenal angka pada anak usia dini. Hal ini dapat dilihat dari uji kelompok besar/ uji lapangan semuanya memperoleh nilai signifikansi $0,000<0,005$ maka $\mathrm{H}_{0}$ ditolak. Dengan demikian dapat dikatakan adanya perbedaan pada rata-rata perlakuan sebelum dan sesudah dan rata-rata skor perlakuan sebelum dan sesudah perlakuan pada proses pembelajaran tali lompat dengan menggunakan media TALOKA (Tali Lompat Angka) yang telah dikembangkan. Dengan kata lain bahwa dengan menggunakan media TALOKA (Tali Lompat Angka) dapat menstimulasi kemampuan mengenal angka pada anak usia dini.

\section{E. DAFTAR PUSTAKA}

Anggrayni, M., \& Sari, A. M. (2019). Peningkatan Kemampuan Mengenal Angka dengan Menggunakan Media Papan Flanel. Jurnal Pelita PAUD, 4(1), 22-28. https://doi.org/10.33222/pelitapaud.v4i1.823

Gandana, G., Pranata, O. H., \& Yulia Danti, T. Y. (2017). Peningkatan Kemampuan Mengenal Lambang Bilangan 1-10 melalui Media Balok Cuisenaire pada Anak Usia 4-5 Tahun di TK At-Toyyibah. Jurnal PAUD AGAPEDIA, 1(1), 92-105. https://doi.org/10.17509/jpa.v1i1.7160

Hasanah, L., \& Nurhasanah, A. (2020). Kemampuan Membaca Permulaan Melalui Penggunaan Media Papan Flanel Anak Usia Dini 4-5 Tahun. Jurnal PAUD AGAPEDIA, 2(1), 12-22. https://doi.org/10.17509/jpa.v2i1.24384

Jamaris, M. (2006). Perkembangan dan Pengembangan Anak Usia Taman KanakKanak. Jakarta: Grasindo.

Permendikbud, R. I. (2014). Peraturan Menteri Pendidikan dan Kebudayaan Republik Indonesia Nomor 137 Tahun 2014 Tentang Standar Nasional Pendidikan Anak Usia Dini. Jakarta: Mendiknas.

Rahman, T., Sumardi, S., \& Fuadatun, F. (2017). Peningkatan Kemampuan Anak Usia Dini Mengenal Konsep Bilangan melalui Media Flashcard. Jurnal PAUD AGAPEDIA, 1(1), 118-128. https://doi.org/10.17509/jpa.v1i1.7167 
J-SANAK: Jurnal Kajian Anak

(p-ISSN: 2686-5343 |e-ISSN: 2715-7989)

Vol.(2)(01), (Juli-Desember)(2020), (Halaman)(49-59)

DOI: https://doi.org/10.24127/j-sanak.v2i01.384

Sugiyono, P. (n.d.). Dr. 2010. Metode Penelitian Kuantitatif, Kualitatif, Dan R\&D. Bandung: CV Alfabeta.

Suharsimi, A. (2006). Prosedur Penelitian Suatu Pendekatan Praktik. Jakarta: Rineka Cipta.

Sumardi, S., Rahman, T., \& Gustini, I. S. (2017). Peningkatan Kemampuan Anak Usia Dini Mengenal Lambang Bilangan Melalui Media Playdough. Jurnal PAUD AGAPEDIA, 1(2), 190-202. https://doi.org/10.17509/jpa.v1i2.9359

Suyanto, S. (2005). Konsep Dasar Pendidikan Anak Usia Dini. Jakarta: Depdiknas. 